Maria A. Burganova Full Member of the Russian Academy of Arts Doctor of Arts Professor, Head of the Department of Monumental and Decorative Sculpture at the Stroganov Moscow State Art Industrial Academ. Deputy Director of the Moscow State Mirector of the Moscour Moscow, Russia

\section{Images of the Grieving Christ in the Museum Collections of Saratov}

Summary: An analytical review of church statues united by the plot "Christ in the Dungeon" from Saratov and the Saratov region museums is presented in the article. Using these examples, the author draws attention to variations of the image of Christ in the last hours before the crucifixion typical of the Russian province. Assessing the wide variety of interpretations of this plot, it is necessary to take into account that, in Russia, the statues of Christ in the dungeon were created mostly in provincial workshops where the craftsmen used engraved illustrations as the source and an example. For instance, the illustrations for the Piscator Bible [Theatrum Biblicum: 1646] had served as iconographic examples for many icon-painters and carvers since the $17^{\text {th }}$ century. It should be noted that most often these engraved examples provided only an impetus for sculptors and were sometimes interpreted quite arbitrarily. These circumstances gave certain freedom to sculptors and carvers creating artistic images distinguished by sculptural diversity and vivid emotional character.

The statues of Christ in the dungeon are typical of the Russian province and represent images combining some details of the iconographic versions of Ecce Homo and The Man of Sorrows. Ecce Homo is an image of suffering, awaiting the crucifixion Christ with traces of flagellation, with chained or tied hands, in the Crown of Thorns, in shackles and a purple robe. As the Man of Sorrows, Christ is presented thoughtful, with a bowed head. His hand is pressed to his cheek, the wounds from the spear and nails received at the time of the crucifixion are visible on the body.

Having become a kind of connection between the three museums, there are nineteen artworks in the Saratov collection of sculptures with the plot "Christ in the Dungeon". These statues were moved from one museum to another throughout the $20^{\text {th }}$ century. Initially, this group of monuments was collected in a small Petrovsky Museum of Local Lore. In the summer of 1923, members of an ethnographic expedition removed the statues of Christ in the Dungeon from the surrounding churches. At the same time artist F. Kitavin made very accurate watercolour sketches reliably capturing the colour features of the statues and their vestments. Currently, these watercolour sketches with explanatory inscriptions may be regarded as a documentary source.

Keywords: Ecce Homo, Christ in the Dungeon, Man of Sorrows, the Piskator Bible, city of Saratov, Saratov region, Russian province
The depiction of Christ in the last hours before the crucifixion, often called Christ in the Dungeon, is one of the most popular plots of gospel history in church sculpture [Belting. 1990: 5-20]. Statues could be found in the Russian province almost everywhere. They were especially widespread during the 18th-19th centuries.

Generally, Christ is represented sitting with a sad bowed head. There is a Crown of Thorns on the head of the Savior. Drops of blood are flowing down his face. Traces of flagellation are on his back, arms and legs. Most often, Christ is depicted wearing only a loincloth; however, Christ in the dungeon is frequently dressed in a long chiton as well. There are compositions with the instruments of the Passion: a pillar of flagellation, chains. All images are polychrome.

In the Orthodox interpretation of the image of Christ in the dungeon, the theme of physical torment takes the secondary role. Christ is sorrowful and concentrated in his sublime meditation. He is estranged from the painful reality and, being the object of insults and beatings, is as if beyond these events. The right hand of Christ is raised to his face. Nevertheless, Jesus is not covering his head from the blows but only slightly propping his cheek with his palm or touching his temple with his fingers, giving an expression of mournful thoughtfulness to the image

Some researchers [Arras: 2010. P. 96-105] believe that the iconography of this plot originated in Byzantium in the 13th century. Located in Santa Croce in Gerusalemme, a mosaic icon with an image of Christ in a tomb with the instruments of the Passion is considered to be the impetus. The plot became widespread owing to the legend, reflected in works of art many times, according to which Christ, wearing his Crown of Thorns and with the bleeding wounds, appeared on the altar during a service in the church of Santa Croce in Gerusalemme where Pope Gregory the Great was saying Mass. Undergoing multiple changes over a period of one and a half or two centuries, the image had developed to the form known today and had become widespread in Europe by the late 15th and early 16th centuries. The image of suffering Christ in this iconography is found in paintings and sculptures. Sorrowing Christ (1450-1460) by the Alsatian master (the Museum of Fine Arts, Boston), Ecce Homo (1490-1493) by Albrecht Durer with the iconography of The Man of Sorrows (Staatliche Kunsthalle Karlsruhe), Christ on the Cold Stone (1500) by Jan Bormann (M-Museum, Leuven), Grieving Christ (1500) by the Brabant master (the Suermondt-Ludwig-Museum, Aachen) and many others are among them.

Albrecht Durer's small graphic series The Passion of the Lord with the image of the suffering Christ on the title page was published in 1511. This iconographic image began to circulate due to the means of production graphics. This plot was included in the mandatory list of Stations of the Cross and in the iconographic program of each Catholic church.

This tragic image reached its height of popularity in the 18th century. The plot started to appear on the territories of Eastern Europe and especially in Russia where the figure of the Grieving Christ, or otherwise called the Pensive Christ, could be 
found in almost every provincial church. A number of changes had occurred in the established iconography of this plot by this time. This was due to the new area of the image appearance, its free emotional interpretation, the fusion of several iconographic versions into one [Burganova, 2018: 110-115].

Russian masters instantly absorbed Western European trends; however, they did not copy the samples but freely interpreted the shape of the figure as well as its iconographic form.

The statues of Christ in the dungeon are typical of the Russian province and represent an image which unites some details of the iconographic versions of Ecce Homo (the image of suffering awaiting the crucifixion Christ with traces of flagellation and chained or tied hands, with a Crown of Thorns, in shackles and a purple robe) and Man of Sorrows where Christ is represented pensive with a bowed head. His hand is supporting his cheek, wounds received at the time of the crucifixion from the spear and nails are visible on the body.

There are nineteen works which have become a kind of a connecting link between the three museums in the Saratov collection ${ }^{1}$ of artworks on the plot Christ in the Dungeon. These statues were moved from one museum to another throughout the 20th century. Initially, this group of monuments was collected in a small Petrovsky Museum of Local Lore. In the summer of 1923, members of an ethnographic expedition removed the statues of Christ in the Dungeon from the surrounding churches. At the same time, artist F. Kitavin made very accurate watercolour sketches reliably capturing the colour features of the statues and their vestments.

The choice of the expedition members is interesting: only the statues depicting Christ in the dungeon were purposefully collected. The collection, which included sculpture, graphics, and archival documents, was in the Petrovsky Museum of Local Lore until 1974. According to Radishchevsky museum staff, the sculptures had been completely neglected, and, therefore, were taken to Saratov. In Saratov, the collection was distributed between two museums. The sculptures were transferred to the Radishchevsky Museum and Kitavin's unique watercolours, on which these works of sculpture were documented with precision at the time of their museumification in 1923, to the Museum of Local Lore.

The sculptural group Laying the Crown of Thorns from the church in the Pestrovka village in the Petrovsky district of the Saratov province is an outstanding work of this collection. The plot "The Crowning of Jesus with Thorns" has been widespread in Europe since the 12th century. The earliest images include the ceiling mural in St. Martin's Church in Zillis (1130), canton of Graubünden, Switzerland. However, "The Crowning of Jesus with Thorns" has been depicted most frequently in Christian art since the 14th century as a result of the Finding of the Crown of Thorns as a holy relic and its transfer to the Notre Dame Cathedral. The Crown of Thorns is mentioned in three gospels: "...

\footnotetext{
The Saratov collection is a conditional term describing sculptures and graphics on the theme of Christ in the Dungeon from the Radishchev State Art Museum in Saratov and the Saratov Regional Museum of Local Lore.
}

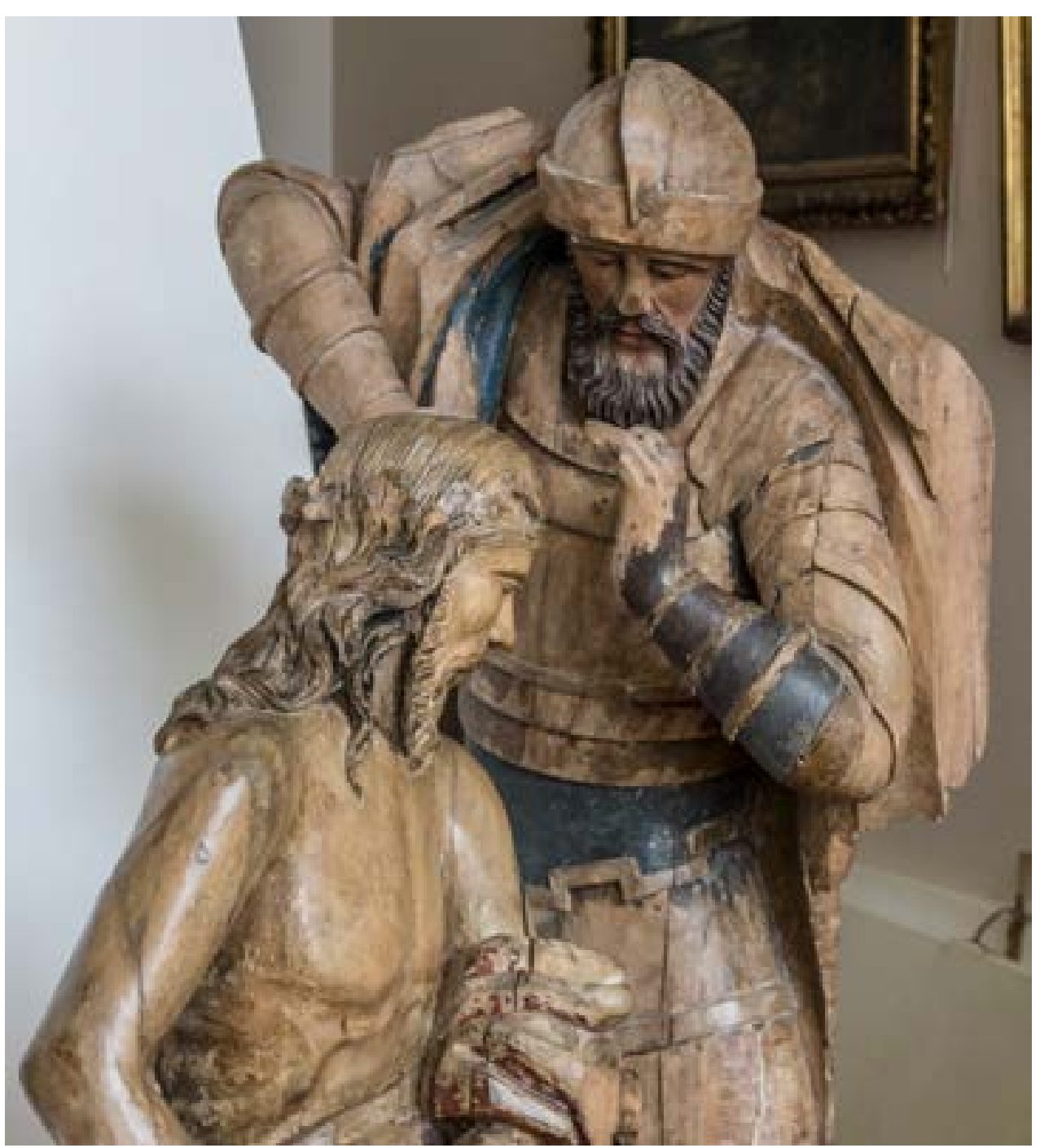

Ill.1 Grieving Savior. 18th century. Wood, gesso, tempera, forged metal (nails); carving, painting. $143 \times 62 \times$ 52.cm; Roman Warrior. 18th century. Wood; carving, painting. $170 \times 63 \times 30 \mathrm{~cm}$

and twisting together a crown of thorns, they put it on his head and put a reed in his right hand. And kneeling before him, they mocked him, saying, "Hail, King of the Jews!' (Matthew 27:29); ... and they put on Him purple, and having twisted together a crown of thorns, they placed it on Him (Mark 15:17); ... and the soldiers twisted together a crown of thorns and put it on his head and arrayed him in a purple robe (John 19: 2)".

The artist who created this sculptural group was obviously familiar with the Piscator Bible [Theatrum biblicum: 1646]; its illustrations served as iconographic examples for many icon-painters and carvers dating back to the 17th century [Piscator Bible: 2019. 
S. 166-167]. The illustrated Bible contained several hundred engravings in editions of different years. Its copies were not only in the libraries of the Armory Chamber, in the Trinity Lavra of St. Sergius and Moscow Patriarch Hadrian's library, but also in libraries remote from the capital city of cultural centers and monasteries. The publication combines the engravings by M. van Heemskerk, K. van Mander, M. de Vos, P. Brila, M. Coxie, A. de Verdt, and others.

It is known that a carver had to provide engraved sheets ("samples", "translations") as examples of his future work in order to be hired [V. Baranenkov: 2006. S. 139.] These were not necessarily pages from the Bible, but could be "translations" taken from these illustrations, some of which are preserved in museum collections. This important detail sheds light on the carvers and icon painters' method of work. Such "translations", as a rule, had the signature of the owner, which in some cases allows to attribute the work more accurately.

The composition "Laying the Crown of Thorns" 2 from the church in the village Pestrovka in the Petrovsky district of the Saratov province, undoubtedly, quotes from one of the pages with the image of this scene in the Piscator Bible: Christ with a naked torso is sitting with his tied hands to the right which almost exactly repeats the composition in the engraving ${ }^{3}$. Crimson vestments descend from the waist to the ankles, leaving bare feet open. In the background, there is a figure of a Roman warrior in armour and in a helmet with uplifted hands. It should be noted that this composition has become widespread in icon painting ${ }^{4}$.

In the sculptural group from the village of Pestrovsk there is a Roman warrior in armour. The figures of Christ and the warrior are not connected by a single pedestal. In this monumental composition, it is possible that there could have been another figure of a warrior, and this would have corresponded to the traditional European compositional schemes.

The monument is pictured in Kitavin's watercolour paintings. A white veil with embroidered red crosses is thrown over Jesus's lap. Perhaps it is catasarka, an altar cloth, traditionally decorated with crosses on four sides, which was taken from the church at the time of the removal of the sculpture in order to transfer it to the museum. In Kita-

2. Grieving Savior. 18th century. Wood, gesso, tempera, forged metal (nails); carving, painting. $143 \times$ $62 \times 52$. Radishchevsky Museum SK-318, KP 5012. Roman Warrior 18th century. Wood; carving (2) SK-322, KP 5016 CSaratov State Radischev Art Museum

Laying the Crown of Thorns. The Piscator Bible. 1643. State Tretyakov Gallery. Inv. M-56 (I-189) L. 357. The icon Laying the Crown of Thorns from the Vvedenskaya Church in Barashy. Late 17th - early
18th century. State Tretyakov Gallery Inv. 22282. Icon Flagellation of Christ. Laying the Crown of Thorns from the Vvedenskaya Church in Barashy. The first half of the 18th century. Tretyakov Gallery Inv. 22282. Icon Laying the Crown of Thorns from the Church of the Assumption (Ou Lady of Grebnersaya) o Labyana Square in Moscow. 18th century. State Tretyakov Galley. Inv. 24478 vin's watercolour painting, there is an inscription in which the Roman warrior is mistakenly called Pilate ${ }^{5}$

The monument, sharing similarity with "The Man of Sorrows" iconography, is stored in the Radishchev Museum ${ }^{6}$. The blue-eyed Christ is slightly touching the temple with his right hand, his head is inclined to the right, his left hand is pressed to the torso at the level of the abdomen. There is a bleeding spear wound right on the ribs. Traces from the nails are visible on both hands. Revealing powerful hips, large folds of the blue loincloth are high on the sides. The shins, on the contrary, are thin, creating a contrast with the massive volume of the hips.

The artist took the painting of the figure very seriously. The cheekbones and ears are touched up with pink, lips are painted, the navel is accented; nipples, drops of blood, dripping from under the Crown, are marked with dark red; the blue irises of the wideopen eyes are emphasized with the bright whites.

However, generally, in the Orthodox interpretation, the two images - Christ, brought before the crowd before the crucifixion, and Christ after the execution on the cross, were united into one. In addition, the iconographic variants of Christ in the Dungeon, Christ at the Column, the image of weakened Christ sitting on a stone at Calvary and others may be seen in the figures of sitting thoughtful Christ who looks calm despite the bleeding traces from the beatings.

Among the sculptures, there are examples of the emphasis of his nakedness, illustrating one of the rarely depicted tortures of Christ. This topic of mental suffering caused by shame at the time of public undressing became especially popular during the 18th century in the baroque art of Western Europe, when nudity as a symbol of slavery was the most powerful expression of humiliation and shame for an honest person.

The theme of Christ's nakedness is reflected in the sculpture from the village of Spasskoye-Aleksandrovo, Petrovsky district, Saratov province ${ }^{7}$. Christ is depicted without a loincloth. The fabric thrown over the knees leaves the bare buttocks, lower abdomen and Christ's upper thighs open. The folds of the fabric are carved with a special decorative technique using loops similar to petals. Despite the dramatic nature of the plot, Christ has a calm, estranged, lost in thought expression on his face. It seems that his gaze is fixed on himself.

The sculpture is pictured in F. Kitavin's watercolour painting ${ }^{8}$. On Jesus's shoulders, there is a red veil with a lining, trimmed around the edge with yellow gold fringe and embroidered with yellow thread at one end. Perhaps this is the katapetasma (the curtain between the Royal Gates and the Throne) brought to the museum along with oth-

5. Kitavin F. Christ and Pilate. Laying the Crown of Thorns. 1923. Paper, watercolour $33.6 \times 23.5$. Inv. QMS 6812.

eon 18th centry. Wood, $116 \times 40 \times 28$. Radischevsky Museum. SK 314, KP 5008.

Christ in the Dungeon. Wood gesso, tempera, forged metal (nails); carving painting $121 \times 50 \times$ 45. Radischevsky Museum, SK 316 KP 5010. OSaratov State Radischev Art Museum

Kitavin F. The True Christ. 1923. Watercolour on paper. 33.3 × 23.2. Inv. QMS 57722/19. 


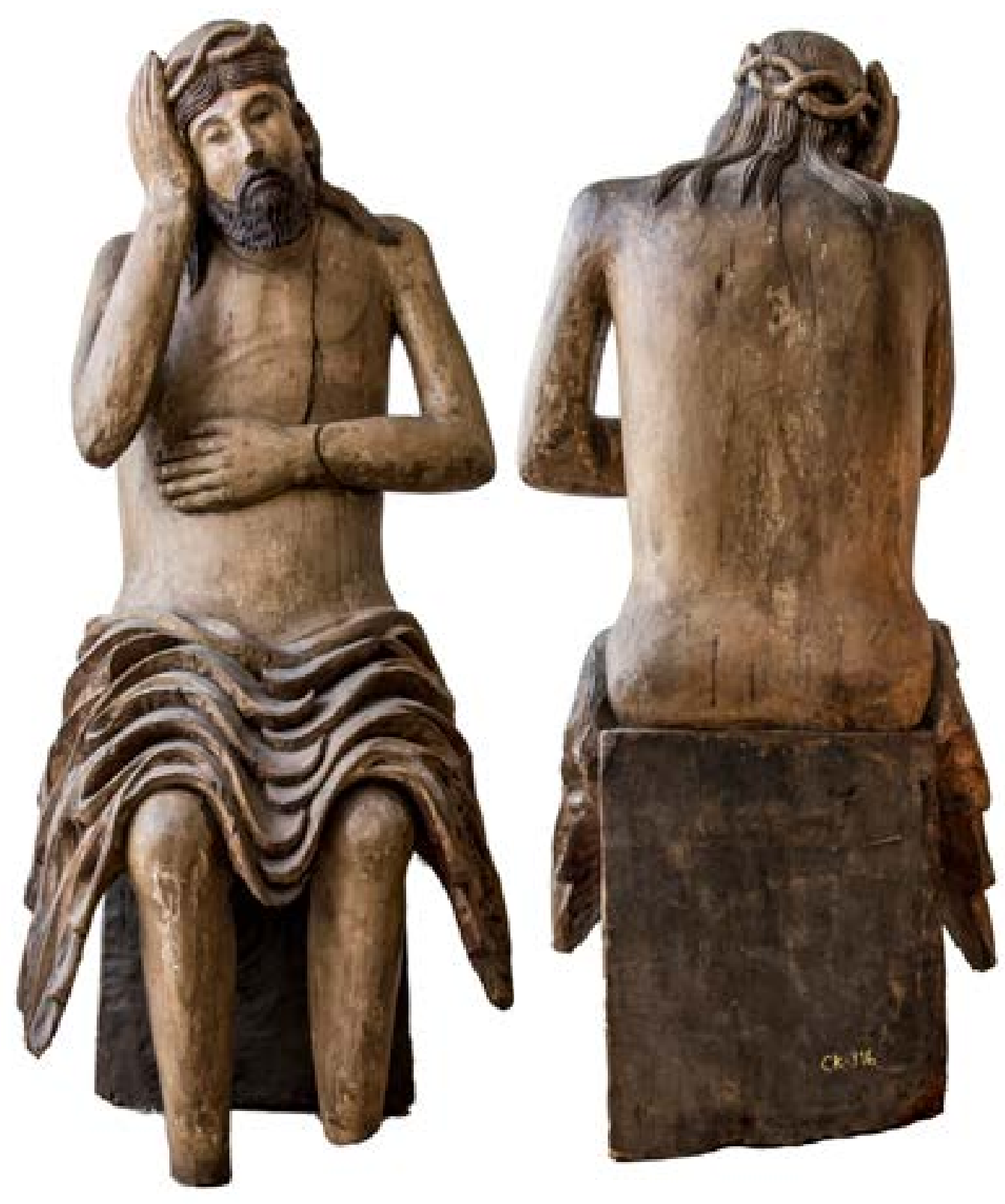

Ill.2 Christ in the Dungeon. Wood, gesso, tempera, forged metal (nails); carving, painting. $121 \times 50 \times 45$.cm er church utensils, or it was simply used to hide the sculpture during transportation. In accordance with the gospel text, the scene of the ridicule of Christ and dressing him in a scarlet robe, which was represented by the Roman legionnaire's red short cloak, is reproduced accidentally or intentionally.

It can be seen that, at the time of transfer to the museum, the figure already had significant losses - both feet were missing. However, the painting was preserved. Drops of blood on the torso, arms, legs are clearly visible. The intense cherry colour of the fabric lying on Christ's lap can be seen distinctly.

It should be noted that the theme of nudity in the images of the Pensive Christ is rare. Most often, Christ was depicted half-naked in a loincloth in this iconographic plot. The colour of the loincloth varied. White, blue, green, red colours were the most common ones. The shape of the loincloth is diverse - it may be not too big or laid in small folds. Tied in complex knots, it may come down with long folds on the sides, or it might even be a large drapery, sometimes painted with large flowers. For instance, one of the sculptures depicting Christ in the dungeon is distinguished by a peculiar interpretation of the loincloth, painted in bright orange ${ }^{9}$. Decorated with numerous folds, gathered on the hips and laid like some kind of hoops on the sides, the loincloth was unusually lowered down, exposing the lower abdomen and the beginning of Christ's thighs. Its edge is raised to the thigh, revealing the left knee.

Sculptural images of the Pensive Christ were often placed in dark niches in the walls of churches or special dungeons, the so-called praetors, were built for them, sometimes decorated with gilded carvings, looking like separate chapels with wreathed columns and with velvet or muslin curtains in the small windows. One of Kitavin's watercolours depicts a sculpture of Christ in the dungeon from the village of Dmitrievsky Chardym in the Petrovsky district of the Saratov province ${ }^{10}$. The dungeon with three small windows with decorative sashes is painted light blue inside. The dungeon door is wide open. There is a poorly straightened white with thin gray stripes undershirt on the figure of Christ. Strangely tied around the head with a large knot, a golden veil, embroidered around the edge, is thrown over it, descending onto the arms. The fabric is clearly held by thin ropes. It seems as if it served as packaging material during transportation. It is hard to imagine that the figure of Christ could have been clothed so casually. Nevertheless, it is also strange that Kitavin, whose works are characterized by rare accuracy, did not straighten the vestments though he obviously had the opportunity to do it. Instead, he documented the statue in this state, definitely attaching great importance to the fact of documentary record.

Clearly, Kitavin's watercolours, on which church sculptures are depicted with extraordinary accuracy at the time of their transfer to the museum, became the most important documentary record addition to the Saratov collection of sacral sculpture. The

\footnotetext{
9. Christ in the Dungeon. 18th century. Wood, gesso, tempera; carving, painting. $107 \times 36 \times 36$
}

Radischevsky Museum, SK 319, KP 5013 .
10. F. Kitavin. Christ in the Dungeon. Watercolour on paper. $33.6 \times 23.5 \mathrm{~cm}$. Inv. No. SMK6814. 
artist depicted fabric vestments of statues in some of his works. Traditionally, the statues showing the Pensive Christ were dressed in real church clothing according to church holidays or were covered with expensive fabrics. Shoes were often placed nearby or, if possible, they were put on his feet.

Information about the vestments on statues is found frequently in the comments of researchers of Russian wooden sculpture. Sculptures had a wardrobe, consisting of several sets of specially tailored clothes. When looking at Kitavin's documentary watercolours, multilayered vestments of Christ can be studied. The watercolours The True Christ from Lunacharskoye village in the Petrovsky district of the Saratov province ${ }^{11}$ and The True Christ from Buzovlevo village in the Petrovsky district of the Saratov province ${ }^{12}$ are vivid examples. These multilayered vestments are traditional in the Christian church and may be explained by the symbolic reflection of the hierarchical movement from one rank of clergyman to another, higher. However, the meaning of multilayered vestments is much deeper than the outer manifestation. It reflects the idea of spiritual perfection of a person. Therefore, the priest's clothing with the bishop's on top subsequently covered the deacon's clothing.

As a rule, several changes of clothing were also created for statues. A set which included the upper and lower dress was for the so-called everyday wear; black mourning robes were put during Lent; rich vestments made of brocade with velvet or from other elegant fabrics of gold or white colours were put during holidays. The change of clothing was accompanied by prayer chants with such metaphorical images as "the robe of truth and joy", a belt - "the power of truth", headwear - "a cowl of kindness and hope of salvation", sandals - "for preparing the gospel to the world". Currently, all cloth vestments have been lost. They can only be seen on Kitavin's watercolours done with documentary accuracy.

On all the sculptures from the Saratov collection, Christ is dressed in a loincloth, and only in one case there is a long dark red chiton on him ${ }^{13}$. The sculpture differs from the rest of the statues in style and sculptural features and is more in line with the Catholic tradition of interpreting such image. Jesus hands are crossed on his chest. A rope with a large knot is tied around his wrists. The head, crowned with thorns, is slightly inclined to the left. Strands of hair, ending with graceful, sharp curls, are lying on the shoulders

According to legend, recorded in the inventory book by K. Zhuravlev, the statue was "donated to the monastery by a dissenter Ural Cossack during the times when it was the Old Believers monastery". Gavrilova published information according to which the statue, presented by the Ural Cossack, was in the chapel of the Old Believers Central Nikolsky Monastery [Gavrilova: 2008. Pp. 174-180].

F. Kitavin. The True Christ. 1923. Watercolour on paper. $33.5 \times 23.5$ Inv. SMK 57722/18 2. F. Kitavin. The True Christ. 1923 . Watercolour on paper. $33.5 \times 23.6$ Inv. SMK 57722/20. 13. Christ in the Dungeon. 19th cen. Wry. Wood, Radischevsky Museum, SK 309, KP 4932. OSaratov State Radischev Art Museum
Given that the Ural Cossacks, who were Old Believers, took part in European campaigns, this version appears quite convincing, especially taking into account the fact that the Cossack regiments were part of the corps under the general command of Alexander Mikhailovich Rimsky-Korsakov who controlled the Belarusian provinces, was the Military Governor in Vilna in 1806-1808, the Commander of Troops in the western provinces, and ruled Lithuanian provinces in 1812-1830's. These are the regions where church sculpture became widespread.

In Poland, Belarus, Western, Middle and Northern Lithuania, the iconographic version of depicting Christ in Long Vestments had been popular since the 17th century and made up more than half of all the images of the Pensive Christ on these territories [Surdokayte: 2009. Pp. 50-66]

Christ was often depicted shackled in the dungeon. One of the sculptures from the Radishchevsky Museum illustrates this scene ${ }^{14}$. The combination of the parts executed extraordinarily thoroughly and the others which were left absolutely without carving is a peculiarity of this sculpture. For instance, the face, the left ear, the chest are carefully carved; however, the details on the back are not even outlined. The Crown of Thorns is carved only till the back of the head, then it becomes a smooth ribbon not enriched with carvings which is surprising since the Crown, having a special sacred meaning, was always done completely. With shallow cuts, the hair is divided into curls only lying on the shoulders; it is not divided into strands at the back. The back and the loincloth behind are left like a simple unprocessed solid mass, becoming a strangely shaped stand looking like a wedge going down from the sacrum. Clearly, this part had a certain functional value, for example, acting as a fixing for attaching the figure to the seat.

The sculpture is carved from almost solid wood, except for a small part. The elbow of the right hand is mounted and fixed with wooden nails.

Jesus has a special facial expression associated with an unusual eye characterization. The right eye is open, and a brown iris is visible from under the drawn eyelashes. The left eye is closed. The face is glazed with a pink pigment, which can be seen on the lips and cheeks. A thorny wreath assembled from equivalent diamond-shaped segments is on the head of Christ. The large folds of the loincloth, lowered so much from the waist that naked loins are visible, are completed symbolically and decoratively. There are carved wooden shackles on Christ's feet.

Another figure of Christ in shackles ${ }^{15}$ is stored in the Saratov Regional Museum of Local Lore. The sculpture has several features. The position of Christ's feet is unusual. The Savior is depicted sitting on a high seat, his legs do not reach the floor, the shackled feet are hanging (only the right ring is preserved). In addition, there are no signs of flag-

14. Christ in the Dungeon. 18 th century. Wood, gesso; carving, painting. $152 \times 41 \times 48$. Radischevsky Museum, SK 313, KP 5007. OSaratov State Radischev Art Museum

Christ in the Dungeon. Saratov Volgo Region, 18th century. Wood gesso, tempera, forged metal (nils); carving painting. Wooden shackles. $136 \times 45.5 \times 47$; Wood, gesso, tempera, forged metal Museum of Local Lore. No. SMK 74507, KP 55b Inv. SKL No. 75. 


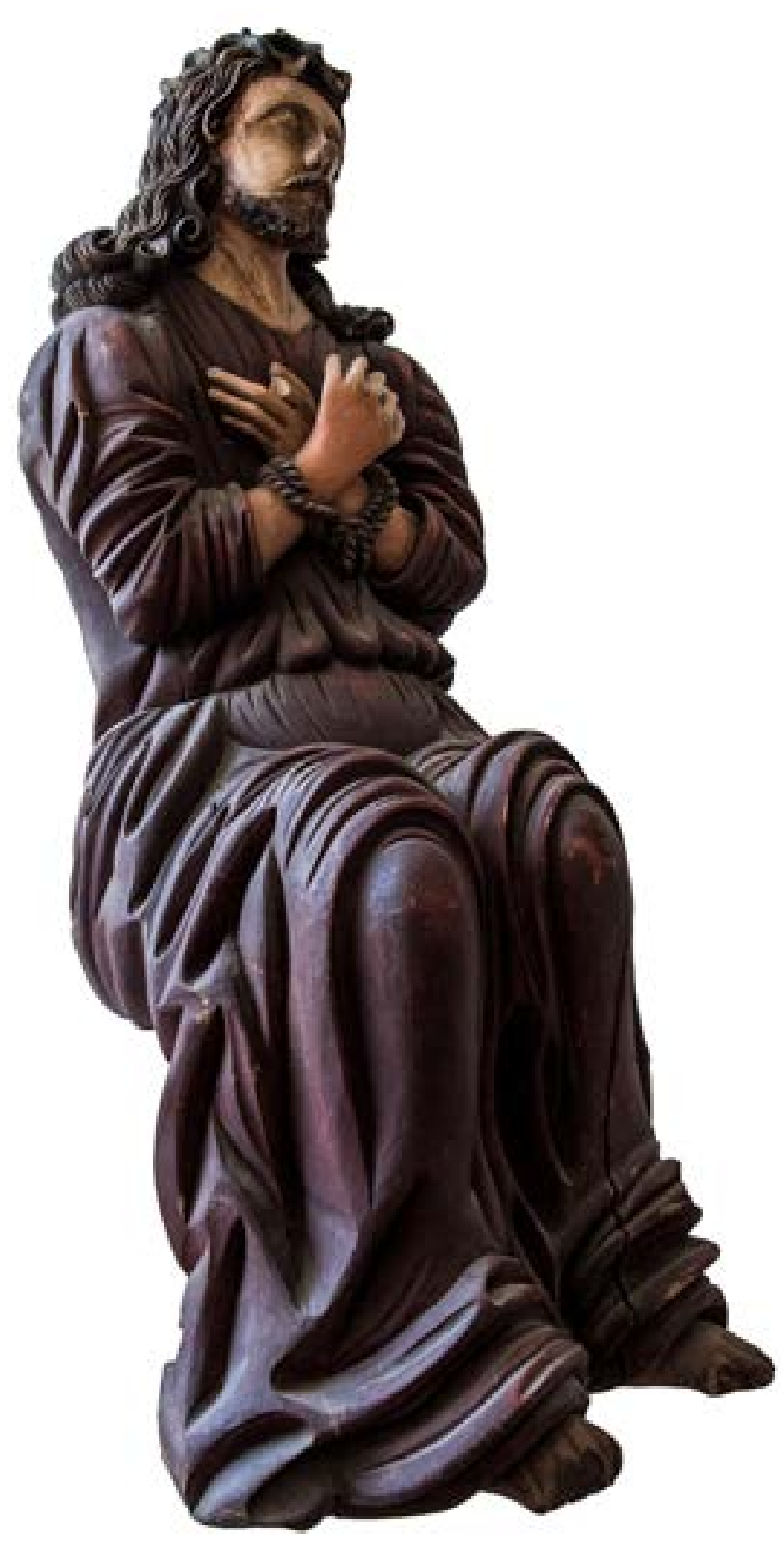

Ill.3 Christ in the Dungeon. 19th century. Wood, gesso, tempera; carving, painting. $113 \times 53 \times 43 \mathrm{~cm}$ ellation on the body of Christ. In practice, only the scene of ridicule is shown: Christ is crowned with thorns symbolizing a false crown but the torture itself has not yet occurred.

Christ's head is turned to his right shoulder. Strands of hair are scattered on the shoulders and the back. The left ear is fully open, which symbolizes the theme of readiness to listen to the voice of God. There is a green Crown of Thorns with inserted spikes on the head. Christ's body is of medium-dark carnation; the hair, beard, mustache, eyebrows are dark brown; eyes are brown, lips are pink. The palm of the right hand is raised to the cheek, the left hand is pressed to the torso. The sculptural interpretation of large ribs attracts attention. The red loincloth, modeled by many folds, is descending from the left side to the middle of the lower leg and is rising from the other side, exposing the right knee. This detail, the naked knee, can be seen several times on Saratov sculptures. All works were done by different artists, so an author's personal artistic technique can be excluded. Perhaps an iconographic pattern (such as an engraving or sculpture), which formed the basis for such an interpretation of the loincloth, existed.

The smiling Christ with closed eyes ${ }^{16}$ is among the most expressive images in the Saratov collection. Jesus is presented seated in a traditional position: the palm of his right hand is near his cheek, his head is tilted to the right, wavy hair are spread out over his shoulders, his left hand is pressed to the torso at the level of the abdomen. The sculpture is distinguished by a number of unique details. The Crown of Thorns is not carved from the same single solid wood block as the figure, but is woven from a rod and secured with forged nails. The wide fabric, hiding the figure from the waist to the middle of the shins, is laid in large folds except from the left side, leaving Christ's left foot naked from the knee.

An unusually peaceful facial expression with a smile on the lips and closed eyes can be considered a peculiarity of the image. Traditionally, opened eyes are interpreted as a symbol of the triumph of life over death, whereas closed eyes as a symbol of death. In this interpretation, they symbolize the expectation of crucifixion and presentiment of Divine immortality in the last hours of the life of Christ as a human - calm, peaceful, allforgiving. The wound on the left of the chest can also be considered unusual, although it is known that the spear struck the crucified Jesus on the right. Similar examples are extremely rare. The wound on the left of the chest can also be seen on Christ in the Dungeon (17th century) from the collection of the Pereslavl-Zalessky Museum Reserve.

Christ is also depicted with closed eyes and a smile on his lips on the statue from Kondol village in the Petrovsky district of the Saratov province ${ }^{17}$. There is not even a hint of suffering in the image of smiling Christ. The palm of his right hand is pressed to his cheek. The left hand is pressed to the torso at the level of the abdomen. The head is pushed forward and slightly inclined. Straight dark hair is exquisitely set. The hair is

16. Christ in the Dungeon. 18th century. Wood; remnants of gesso, tempera; forged metal (nails). 123x30x34. Radischevsky Museum, SK 315, KP 5009.

- Christ in the Dungeon. 19th century. Wood, gesso, tempera; carving, painting $109 \times 48 \times 40$. Radischevsky Museum, SK 320, KP 5014. 
thrown back from the face over the shoulders onto the back. The folds of the loincloth are completed with decorative technique. The sculpture was depicted in Kitavin's watercolour in $1923^{18}$. The figure is presented in a vestment, a white cloak with a lace edge. A coloured medallion, possibly painted on enamel, on a red ribbon is on Christ's neck.

A number of sculptures from the Saratov collection definitely belong to one artist. All of them were created based on one model. This indicates the existence of a sculptura workshop in the region where carved decorations and statuary sculptures for churches were created. Three statues from Yazykovka village (Petrovsky district of Saratov province), Russkaya Norka village and from one of the villages of the Kuznetsk district located near Petrovsk share not only artistic style and sculptural identity, but also the geometric match of the profile contours. The torsos of all three figures are unusually flattened whereas the heads, legs and arms are fully carved. In all examples, the Savior is depicted as half-sitted, almost standing. The tips of the fingers of the right hand are slightly touching the temple. The left hand is pressed to the torso at the level of the abdomen. The head is oriented straight and strongly pushed forward. The neck is bowed. Straight dark hair is lying in large locks on the shoulders and on the back. At the temples, the hair is slightly thrown back, revealing huge ears tinted with pink, unlike the rest of the carnation. The loincloth is done decoratively, the folds do not follow the anatomical volumes. On the sides, they are grouped into freely falling vertical almost geometric triangular shapes; in the center, they are laid in a wavy volume, crossing Christ's hips diagonally.

Small differences in the statues can only be found in the interpretation of the loincloth of the sculpture from Russkaya Norka village ${ }^{19}$. The central wave-like fold is laid diagonally and carved mirror-like with respect to the other two measurements.

In Kitavin's watercolour, Christ from Yazykovka village ${ }^{20}$ has dark hair, beard, eyes and eyebrows. The pink carnation is clearly visible. There is a light green loincloth. Red drops of blood and long traces of dissected skin from lashes are depicted on the face, torso, arms and legs. Kitavin documented the absence (almost) of the feet on both legs. The currently lost hand is depicted in the watercolour painting. The palm is unusually far away from the cheek.

Kitavin's works are notable for photographic accuracy, rare for paintings. It can be seen that, at the time of the creation of these watercolour paintings, the statue had a number of losses such as cracks, chips, partial loss of the surface layer which were recorded with amazing accuracy. However, most of the painting was still preserved in 1923.

Assessing the great variety of interpretations of this plot, it is necessary to take into account that, on the territory of Russia, the statues of Christ in the dungeon were created

18. F. Kitavin. The True Christ. 1923. Watercolour on paper. $32.5 \times 23.4 \mathrm{~cm}$. Inv. No. SMK 57722/2 Christ in the Dungeon. 18th century. Wood, gesso, tempera, forged metal (a nail); carving, painting 128x39×34. Radischevsky Museum. SK-317, KP 5011.

20. Kitavin F. The True Christ. 1923. Watercolour on paper. $33.6 \times 23 \mathrm{~cm}$. Inv. No. SMK6813

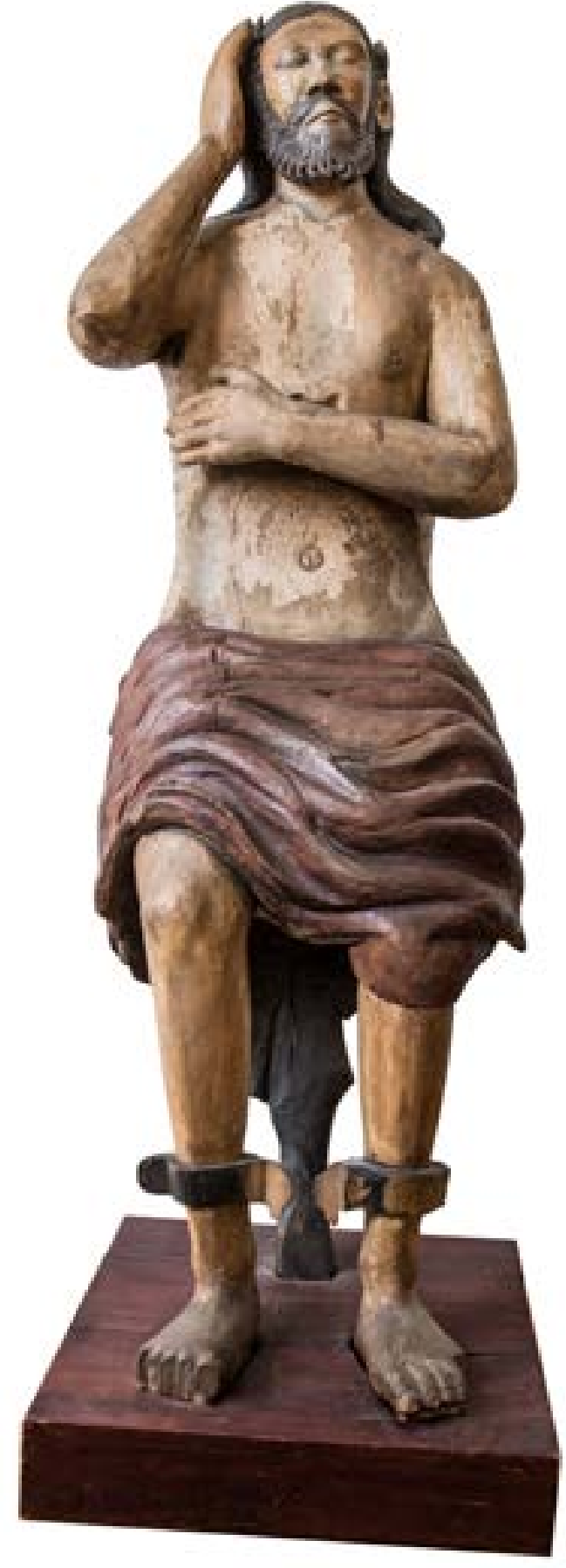

Ill.4 Christ in the Dungeon. 18 th century. Wood, gesso; carving, painting. $152 \times 41 \times 48 \mathrm{~cm}$ 
mostly in provincial workshops, where the artists had only engraved illustrations which were sometimes interpreted quite voluntarily. These circumstances gave sculptors and carvers a certain freedom to create sculptural images, distinguished by their sculptural diversity and vivid emotional characters.

\section{REFERENCES}

(Articles from Scientific Journals)

1. Girelli, Francesca. 2018. "A masterpiece by the Master of the Courajod Christ in Normandy: a reconsideration of the crucifix of Saint-Marcel and other Norman Romanesque sculptures", Sculpture Journal, Liverpool University Press, vol.27, issue 2, pp. 157-176 https://dol org/10.3828/sj.2018.27.2.2 (in English)

2. Paoletti, J.T. 1992. "Wooden Sculpture in Italy as Sacral Presence", Artibus et Historiae, 13(26) DOI: $10.2307 / 1483432$ (in English)

3. Girelli, F. 2018. «A masterpiece by the Master of the Courajod Christ in Normandy: a reconsideration of the crucifix of Saint-Marcel and other Norman Romanesque sculptures», Sculpture Journal, vol. 27(2), pp. 157-176. DOI 10.3828/sj.2018.27.2.2 (in English)

(Articles from Proceedings and Collections of Research Papers)

4. Baranenkov, V.Y. 2005. "Pis'mo rezchika XVII v. (iz restavratsionnykh nakhodok)" [“A Letter from a Carver of the $17^{\text {th }}$ Century (from restoration finds)"], Istoriya i kul tura Rostovskoy zemli Materialy konferentsii [History and Culture of the Rostov Region. Materials of the conference] Rostov, 2006. p. 139. (in Russian)

5. Burganova, M.A. 2018. "Niderlandskaya gravyura i skul'ptura Troitskogo sobora TroitseGledenskogo monastyrya Obraz i prototip" "Dutch Engravings and Sculptures of the Trinity Cathedral of the Troitse-Gledensky Monastery. The Image and The Prototype"], Sbornik "Arkhetip $i$ universalii $v$ iskusstve khristianskogo mira ot antichnosti do sovremennosti: izobrazitel'noye i mo-numental'no-dekorativnoye iskusstvo, arkhitektura i predmet-noprostranstvennaya sreda» XXVI Mezhdunarodnyye Rozhde-stvenskive [Collection "Archetype and Universals in the Art of the Christian World from Antiquity to the Present: Visual and Monumental and Decorative art, Architecture and the Spatial Environment" XXVI International Christmas Educational Readings: "Moral Values and the Future of Humanity"] pp. 110115. (in Russian)

6. Gabia Surdokayte. 2009. "Ikonografiya, rasprostraneniye, opredeleniye obraza Spasa Polunoshchnogo v XVII - XX vv v Velikom knyazhestve Litovskom i Litve" [ "Iconography, Polunoshchnogo v XVII - XX vv. v Velikom knyazhestve Litovskom i Litve" " "Iconography, Popularisation, Function of the Image the Pensive Christ in the Grand Duchy of Lithuania and LI Problem in of Iconography]. Moscow, pp.50-66. (in Russian)

7. Gavrilova N.V. 2008. "Katagizatsiya pravosav

( Volga Region Museums"”, Nauchmy sbornik Drevnerusskaya skul'ptura. Vyp. V: Zapat Rossiya - Vostok Dialog "], Nanch [S sientific collection Old Russian Sulpture vol. V: West-

Russia - East. Dialogue of Cultures]. Moscow, pp. 174-180 (in Russian)

\section{(Monographs)}

1. Arras, D. 2010. Detal'v zhivopisi [Details in Painting], St. Petersburg, pp. 96-105. (in Russian) Paintings of the Passion, Aristide d Caratzas Pub., New York, ISBN 9780892414031 (in English)
3. M-Museum Leuven. Catalog. Leuven, 2014. (in Flemish)

4. Theatrum biblicum hoc est Historiae sacrae Veteris et Novi Testamenti tabulis aeneis expressae. Opus ... editum per Nicolaum Joannis Piscatorem. Amsterdam, 1643; 1650; 1674; Alcmar, 1646.

5. Bibliya Piskatora - nastol'naya kniga russkikh ikonopistsev [The Piskator Bible-a Handbook of Russian Icon Painters], the State Tretyakov Gallery. Moscow, 2019. pp. 166-167

(Thesis and Thesis Abstracts)

6. Burganova, M.A. 2002. Russkaya sakral'naya plastika [Russian sacred plastic]. Doctoral Thesis Abstract. Moscow. (In Russian) 
Мария Александровна Бурганова Действительный член Российской Академии художест Доктор искусствоведени Профессор Заведуюшая кафедрой Монументально-декоративной скульптур Московской государственной художественно-промышиленной академии им. С.Г. Строганов Заместитель директор

Московского государстве Moscow, Russia

\section{Изображения скорбящего Христа \\ в музейных собраниях Саратова}

В статье представлен аналитический обзор церковных статуй, объединенных сюжетом «Христос в темнице», из музеев города Саратова и Саратовской области. На их примере автор обращает внимание на типичные для русской провинции вариации образа Христа в последние часы перед распятием. Оценивая большое разнообразие трактовок этого сюжета, необходимо принять во внимание, что на территории России статуи Христа в темнице создавались большей частью в провинциальный мастерских, где в качестве источника и образца у мастеров имелись гравированные иллюстрации. Например, большой популярностью у мастеров пользовалась Библия Пискатора [Theatrum biblicum: 1646], иллюстрации которой служили иконографическими образцами для многих иконописцев и резчиков, начиная с XVII века. Необходимо отметить, что чаще всего эти гравированные образцы являлись только импульсом для скульпторов и трактовались порой весьма произвольно. Эти обстоятельства дали определенную свободу скульпторам и резчикам при создании художественных образов, отличающихся пластическим разнообразием и яркими эмоциональными характерами.

Статуи Христа в темнице типичны для русской провинции и представляют образы, совмещающий некоторые детали иконографических изводов «Ессе Ното и «Муж скорбей». «Ессе Ното» - изображение страдающего, ожидающего распятия Христа со следами бичевания, с закованными или связанными руками, в терновом венце, в кандалах и багрянице. «Муж скорбей» представляет Христа задумчивым со склоненной головой. Его рука подтирает щеку, на теле видны раны от копья и гвоздей, полученные в момент распятия.

Саратовская коллекция скульптур с сюжетом «Христос в темнице» насчитывает 19 произведений, которые стали своеобразным связующим звеном трех музеев. На протяжении XX века эти статуи перемещались из одного музея в другой. Первоначально эта группа памятников была собрана в небольшом Петровском краеведческом музее. Летом 1923 года участниками этнографической экспедиции были вывезены из окрестных храмов статуи «Христос в темнице». Тогда же художником Ф. Китавиным были сделаны очень точные акварельные зарисовки, которые достоверно фиксируют цветовые особенности статуй и их облачения.
В настоящий момент эти акварельные зарисовки, сопровождаемые пояснительными надписями можно расценивать на документальный источник.

Ключевые слова: Ессе Ното, Христос в темниче, Муж скорбей, Библия Пискатора, город Саратов, Саратовская область, русская провиниия

Изображение Христа в последние часы перед распятием, называемое часто «Христос в темнице» - один из наиболее популярных сюжетов евангельской истории в церковной скульптуре [Belting.1990: 5-20]. Статуи встречались в русской провинции практически повсеместно. Особенно широкое распространение их приходится на период XVIII-XIX вв.

Как правило, Христос представлен сидящим, с печально склоненной головой. На голове Спасителя терновый венец. По лицу стекают капли крови. На спине, руках и ногах - следы бичевания. Чаще всего на Христе только набедренная повязка, но также, нередко, можно видеть сидящего в темнице Христа, облаченного в длинный хитон. Есть композиции с включением атрибутов страстей - столба бичевания, кандалов. Все изображения полихромные.

В православной трактовке образа «Христос в темнице» тема физического мучения отходит на второй план. Христос печален и сосредоточен в своем возвышенном раздумье. Он отстранен от мучительной реальности и, являясь объектом оскорблений и избиений, как бы находится вне этих событий. Десница Христа поднесена к лицу. Но Иисус не прикрывает голову от ударов, а лишь слегка подпирая ладонью щеку или прикасается пальцами к виску, что придает образу выражение скорбной задумчивости.

Некоторые исследователи [Аррас: 2010. С. 96-105] полагают, что иконография этого сюжета зародилась в Византии в XIII в. Импульсом считается мозаичная икона находящаяся в Санта-Кроче-ин-Джерусалемме с поясным изображением Христа во гробе с орудиями страстей. Сюжет получил распространение благодаря многократно отражённой в произведениях изобразительного искусства легенде, согласно которой Христос в терновом венце с кровоточащими ранами явился на алтаре во время службы в церкви Санта-Кроче ин Джерузалеме во время мессы папы Григория Великого. В течении полутра - двух столетий этот образ претерпевая множественные изменения формируется в уже известный сегодня и получает к концу XV-началу XVI в. широкое распространение в Европе. Страдающего Христа в этой иконографии можно увидеть в произведениях живописи и скульптуры. Среди них Скорбящий Христос (1450-1460) Эльзасского мастера (Museum of Fine Arts, Boston), «Ecce homo» (1490-1493) Альбрехта Дюрера с иконографией «Мужа скорбей» (Staatliche Kunsthalle Karlsruhe), Христос на холодном камне (1500) Яна Бормана (M - Museum, Leuven), Скорбящий Христос (1500) Брабантского мастеpa (Suermondt-Ludwig-Museum, Aachen) и многие другие.

В 1511 году вышла в свет малая графическая серия А. Дюрера «Страсти Господни» с изображением страдающего Христа на титульном листе. Благодаря средствам тиражной графики началось активное распространение этого иконографи- 
ческого образа. Этот сюжет вошел в обязательный перечень остановок Крестного пути и находился в иконографической программе каждого католического храма.

Новый пик популярности этого трагического образа приходится на восемнадцатое столетие. Сюжет распространяется на территориях Восточной Европы и особенно России, где фигуру Скорбящего Христа, называемого Спас Полунощный, можно было увидеть почти в каждом провинциальном храме. К этому времени произошел целый ряд изменений в устоявшейся иконографии этого сюжета. Это связано с новым ареалом распространения образа, его вольной эмоциональной трактовкой, сложением нескольких иконографических изводов в один [Бурганова, 2018: 110-115].

Русские мастера мгновенно впитывают западноевропейские веянья, но не копируют образцы, а свободно интерпретируют не только внешний вид фигуры, но даже ее иконографическую формулировку.

Статуи Христа в темнице типичны для русской провинции и представляют образ, совмещающий некоторые детали иконографических изводов «Ессе Ното»изображение страдающего, ожидающего распятия Христа со следами бичевания с закованными или связанными руками, в терновом венце, в кандалах и багрянице, и «Муж скорбей», где Христос представлен задумчивым со склоненной головой. Его рука подтирает щеку, на теле видны раны от копья и гвоздей, полученные в момент распятия.

Саратовская коллекция ${ }^{1}$ скульптур с сюжетом Христос в темнице насчитывает 19 произведений, которые стали своеобразным связующим звеном трех музеев. На протяжении XX века эти статуи перемещались из одного музея в другой. Первоначально эта группа памятников была собрана в небольшом Петровском краеведческом музее. Летом 1923 года участниками этнографической экспедиции были вывезены из окрестных храмов статуи Христа в темнице. Тогда же художником Ф. Китавиным были сделаны очень точные акварельные зарисовки, которые достоверно фиксируют цветовые особенности статуй и их облачения.

Интересен выбор участников экспедиции: целенаправленно собирались только статуи, изображающие Христа в темнице. Это собрание, включающее скульптуру, графику, архивные документы, находилось в Петровском краеведческом музее до 1974 года. Как отмечают музейные сотрудники из Радищевского музея, скульптуры находились в полним забвении, в связи с чем были вывезены в Саратов. В Саратове коллекция была распределена между двумя музеями. В Радищевский музей были переданы скульптуры, в Краеведческий музей -уникальные акварели Китавина, на которых с документальной точностью запечатлены эти произведения скульптуры в момент их музеефикации в 1923 году.

Выдающимся произведением этой коллекции является скульптурная группа «Возложение тернового венца» из храма села Пестровка Петровского уезда

Саратовская коллекция - условный термин, объединяющий произведения скульптуры и графики на тему «Христос в темнице» из Саратовского государственного художественного музея имени А. Н. Радищева и Саратовского областного краеведческого музея.
Саратовской губернии. (Илл. 1) Сюжет «Увенчание Иисуса терновым венцом» получил распространение в Европе с 12 века. К наиболее ранним изображениям можно отнести роспись потолка церкви св. Маритина в Циллисе (1130 г.) кантон Граубюнден, Швейцария. Но наиболее часто «Увенчание Иисуса терновым венцом» стало изображаться в христианском искусстве с XIV века в связи с обретением тернового венца как святой реликвии и переносом его в Собор Парижской Богоматери. Увенчание терновым венцом упоминается в трех евангелиях: « ...и, сплетши венец из терна, возложили Ему на голову и дали Ему в правую руку трость; и, становясь пред Ним на колени, насмехались над Ним, говоря: радуйся, Царь Иудейский» ( Мф 27:29); ...и одели Его в багряницу, и, сплетши терновый венец, возложили на Него (Мк 15:17); И воины, сплетши венец из терна, возложили Ему на голову, и одели Его в багряницу (Ин 19:2).

Мастер, создавший эту скульптурную группу очевидно был знаком с Библией Пискатора [Theatrum biblicum: 1646], иллюстрации которой служили иконографическими образцами для многих иконописцев и резчиков, начиная с XVII века [Библия Пискатора: 2019. С. 166-167]. Иллюстрированная Библия содержала в изданиях разных лет несколько сотен гравюр. Ее экземпляры находилась не только в библиотеках Оружейной палаты, Троице-Сергиевой лавры и патриарха Московского Адриана, но и в библиотеках, отдаленных от столицы культурных центров и монастырей. Издание объединяло гравюры М. ван Хемскерка, К. ван Мандера, М. де Воса, П.Брила, М. Кокси, А. де Вердта и др.

Достоверным фактом является то, что резчику при найме на работу необходимо было предоставить такие гравированные листы («образцы», «переводы») в качестве образцов по которым он будет работать [Бараненков В.Ю. : 2006. С. 139.] Это не обязательно были листы из Библии, но могли быть снятые с этих иллюстраций «переводы», некоторые из которых сохранились в музейных собраниях. Эта важная деталь проливает свет на метод работы резчиков и иконописцев. Такие «переводы», как правило имели подпись владельца, что в некоторых случаях позволяет более точно атрибутировать произведение.

Композиция «Возложение тернового венца» ${ }^{2}$ из храма села Пестровка

Петровского уезда Саратовской губернии в своей основе, несомненно цитирует один из листов Библии Пискатора с изображением этой сцены: Христос с обнаженным торсом сидит, отведя связанные веревкой руки вправо, что почти точно повторяет композицию гравюры ${ }^{3}$. Багряное облачение спускается от пояса до щиколоток, оставляя открытыми босые стопы. Сзади расположена фигура

Скорбящий Спаситель. XVIII в. Дерево, левкас, темпера, кованный металл (гвозди); резьба, роспись $143 \times 62 \times 52$. Радищевский музей СК-318, КП 5012. Римский воин. ХVШІ в. Дерево; резьба, роспись. 170×63×30. Радищевский музей СК-322, КП 5016 ССаратовский государретен, рй худож.

. 
римского воина в доспехах и шлеме с воздетыми руками. Необходимо отметить, эта композиция получила распространение и в иконописи ${ }^{4}$.

В скульптурной группе из села Пестровска присутствует римский воин в доспехах. Фигуры Христа и воина не соединены единым постаментом. Вполне возможно, что в этой монументальной композиции могла быть еще одна фигура воина, что соответствует традиционным европейским композиционным схемам.

Памятник отражен на акварели Ф. Китавина. На колени Иисуса наброшено белое покрывало с вышитыми красными крестами. Возможно, это взятое в храме, в момент выноса скульптуры с целью передачи в музей, облачение на престол катасарка (срачица) - традиционно украшавшееся в четырех сторон крестами. На акварели, сделанной Ф. Китавиным, стоит подпись, где римский воин ошибочно именуется Пилатом ${ }^{5}$

Памятник более точно приближенный к иконографии «Муж скорбей» хранится в Радищевском музее ${ }^{6}$. Синеглазый Христос правой рукой слегка прикасается к виску, голова его склонена вправо, левая рука прижата к торсу на уровне живота Справа на ребрах — кровоточащая рана от копья. На кистях обеих рук следы от гвоздей. Крупные складки голубого набедренника высоко поднимаются по бокам, открывая мощные бедра. Голени, напротив — тонкие, что создает контраст с массивным объемом бедер.

Мастер очень внимательно отнесся к росписи фигуры. Розовым цветом подрумянены скулы и уши, расписаны губы, акцентирован пупок; темно-красным отмечены капли, стекающей из под венца крови, соски; синие радужки широко раскрытых глаз контрастно подчеркнуты светлыми белками.

Но как правило в православной интерпретации два образа - Христос, предъявленный толпе до распятия, и Христос после крестной казни соединились в один. Кроме того, в фигурах сидящего задумчивого Христа, представленного спокойным, несмотря на кровоточащие следы побоев, можно усмотреть иконографические изводы «Христос в темнице», «Христос у столба бичевания», изображение обессиленного Христа, присевшего на камень на Голгофе и другие.

Среди скульптур есть примеры, иллюстрирующие одну из редко изображаемых пыток Христа - подчеркивание его обнаженности. Эта тема душевных страданий, причинённых стыдом в момент публичного раздевания, стала особен-

Икона «Возложение тернового венца» из церкви Введение во храм в Барашах. Конец XVII начало ХУШШ века. ГТГ. Инв. 22282. Икона «Бичевание Христа. Возложение тернового венначало XVII века. ГТ. Инв. 22282. Икона «Бичевание Христа. Возложение тернового вен(1) Икона «Возложение тернового венца» из церкви Успения (Гребневской Богоматери) на ЛуГТГ. Инв. 24478

Китавин Ф. Христос и Пилат. Облечение в терновый венец. 1923. Бумага, акварель $33,6 \times 23,5$ Инв. СМК 6812

Христос в темнице. XVIII в. Дерево, левкас, темпера, кованный металл (гвозди); резьба, роспись $116 \times 40 \times 28$. Радищевский музей. СК 314, КП 5008 но популярной в XVIII веке в барочном искусстве Западной Европы, где нагота как символ рабства являлась наиболее сильным выражением унижения и позора для честного человека.

Тема обнаженности Христа отражена в памятнике из села СпасскоеАлександрово Петровского уезда Саратовской губернии ${ }^{7}$. (Илл.2.) Христос изображен без набедренной повязки. Наброшенная на колени ткань, оставляет открытыми обнаженные ягодицы, низ живота и начало бедер Христа. Складки ткани разделаны особым декоративным приемом с петлями, похожими на лепестки. Не смотря на драматизм сюжета, у Христа спокойное отстранённое, отрешенное выражение лица. Кажется, что взгляд его устремлен в себя.

Памятник запечатлен на акварели Ф. Китавина ${ }^{8}$. На плечах Иисуса - красное покрывало на подкладке, обшитое по краю желтой/золотой каймой (бахромой) и вышитое желтой нитью на одном конце. Возможно, это катапетасма (завеса между Царскими вратами и Престолом), которую привезли в музей вместе с другой церковной утварью, или просто использовали для укрытия фигуры при перевозке. Случайно или намеренно, в соответствии с евангельским текстом, воспроизведён эпизод осмеяния Христа и облачения его багряницей, которую изображал красный короткий плащ римского легионера.

Видно, что на момент передачи в музей фигура уже имела значительные утраты - отсутствовали обе стопы. Однако была сохранена роспись. Отчетливо видны капли крови на торсе, руках, ногах. Явно виден интенсивный вишневый цвет ткани, лежащей на коленях Христа.

Следует отметить, что тема обнаженности в изображениях Спаса Полунощного встречается редко. Чаще всего в этом иконографическом изводе Христос изображался полуобнаженным в набедренной повязке. Цвет набедренной повязки варьировался. Наиболее часто встречаются белый, голубой, зеленый, красный цвета. Форма набедренной повязки разнообразна - она бывает невелика, уложена мелкими складками, или же, завязанная сложными узлами, спускается длинными фалдами по бокам, или вообще представляет собой значительную по размеру драпировку, иногда расписанную крупными цветами. Например один из памятников с изображением Христа в темнице отличается своеобразной трактовкой набедренной повязки, окрашенной в яркий оранжевый цвет ${ }^{9}$. Декорированная многочисленными складками, собранными на бедрах и уложенными как своеобразные фижмы по бокам, набедренная повязка спущена необычайно низко, обнажая низ живота и начало бедер Христа. Ее край поднят на бедро, открывая левое колено.

Христос в темнице. Дерево, левкас, темпера, кованный металл (гвозди); резьба, роспись $121 \times 50 \times 45$. Радищевский музей, СК 316 КП 5010 ОСаратовский государственный художественный музей имени А.Н. Радищева

8. Китавин Ф. Истинный Христос. 1923. Бумага, акварель. 33,3×23,2. Инв. СМК 57722/19.

Христос в темнице. XVIII в. Дерево, левкас, темпера; резьба, роспись. $107 \times 36 \times 36$ Радищевский музей, СК 319, КП 5013 
Часто скульптурные образы Спаса Полунощного помещались в темных нишах в стенах храмов или для них сооружались специальные «темницы», так называемые «преторы», порой украшенные золоченой резьбой, смотрящиеся как отдельные часовенки с витыми колонками и бархатными портьерами или кисейными занавесками в оконцах. На одной из акварелей Ф. Китавина изображена скульптура Христа в темнице из села Дмитриевский Чардым Петровского уезда Саратовской губернии ${ }^{10}$. Темница с тремя небольшими окошками с фигурными переплетами выкрашена внутри голубым цветом. Дверь темницы распахнута. На фигуре Христа надета плохо расправленная нижняя белая рубаха в тонкую серую полоску Сверху накинуто золотистое вышитое по краю покрывало, странно завязанное на голове крупным узлом и спускающееся на руки. Видно, что ткань перехвачена тонкими веревками. Создается впечатление, что она служила скорее упаковочным материалом при перевозке. Трудно представить, чтобы в практике бытования фигура Христа была облачена столь небрежно. Но странно также, что Китавин, чьи работы отличаются редкой документальностью, очевидно, имея возможность расправить облачение, не сделал этого, а зафиксировал памятник в таком состоянии, определенно придавая важное значение факту документального фиксирования

Очевидно, что акварели Ф.Китавина, на которых с необычайной точностью изображены церковные скульптуры в момент их передачи в музей, стали важнейшим документальным дополнением Саратовской коллекции сакральной пластики. На некоторых листах художник зафиксировал тканевые облачения статуй. Традиционно статуи Спаса Полунощного одевали в настоящие церковные одежды соответственно церковным праздникам или укрывались дорогими тканями. Часто подле них ставилась обувь или ее одевали на ноги, если это было возможно.

Сведения об облачении статуй встречаются в комментариях исследователей русской деревянной пластики очень часто. Скульптуры имели целый гардероб, состоявший из нескольких комплектов специально сшитой одежды. Оценивая документальные акварели Китавина, можно рассмотреть многослойность облачения Христа. Яркий пример - акварели «Истинный Христос» из села Луначарское Петровского уезда Саратовской губернии ${ }^{11}$ и «Истинный Христос» из села Бузовлево Петровского уезда Саратовской губернии ${ }^{12}$ Эта многослойность облачений традиционна в христианской церкви и объясняется символическим отражением иерархического движения от одного чина церковнослужителя к другому, вышестоящему. Но смысл многослойного облачения гораздо глубже внешнего проявления и отражает идею духовного совершенствования личности.

Поэтому на дьяконские одежды последовательно накладывались иерейские, потом, сверху, епископские.

Ф. Китавин. Христос в темнице Бумага, акварель. 33,6×23,5см. Инв. № СМК6814

Ф. Китавин. Истинный Христос. 1923. Бумага, акварель. 33,5×23,5 Инв. СМК 57722/18

12. Ф. Китавин. Истинный Христос. 1923. Бумага, акварель. $33,5 \times 23,6$ Инв. СМК 57722/20
Для статуй, как правило, также создавалось несколько смен одежды. Для так называемого повседневного ношения - комплект, включавший верхнее и нижнее платье; черное траурное одеяние на время Великого поста; мажорное, парчовое с бархатом или из других нарядных тканей золотого или белого цветов - на праздничные дни. Переодевания сопровождались молитвенными распевами, где есть и такие метафорические образы: «риза правды и веселия», пояс — «сила истины», головной убор — «куколь незлобия и надежды спасения», сандалии «во уготование Евангелия миру». В настоящее время все тканевые облачения утрачены, их можно увидеть только на акварелях Китавина, исполненных с документальной точностью.

Христос на всех памятниках Саратовской коллекции облачен в набедренную повязку, и только в одном случае изображен в длинном темно-красном хитоне ${ }^{13}$ (Илл. 3). Скульптура отличается от остальных статуй стилистикой и пластическими особенностями и более созвучна католической традиции трактовки данного образа. Руки Иисуса скрещены на груди. Запястья перевиты веревкой с крупным узлом. Голова, увенчанная терновым венцом, слегка склонена влево. Пряди волос, лежащие на плечах, завершаются изящными крутыми локонами.

По преданию, зафиксированному К. И. Журавлевым в инвентарной книге, статуя была «пожертвована в монастырь уральским казаком-раскольником в бытность монастыря старообрядческим». Н. Гаврилова публикует сведения, из которых следует, что статуя находилась в часовне старообрядческого Средне-Никольского монастыря и была переда туда уральским казаком [Гаврилова: 2008. С. 174-180].

Учитывая, что уральские казаки-старообрядцы принимали участие в европейских походах, такая версия выглядит вполне убедительной. Особенно принимая во внимание тот факт, что казачьи полки входили в корпус, находившийся под общим командованием Александра Михайловича Римского-Корсакова, который управлял белорусскими губерниями, в 1806-1808 годах был военным губернатором в Вильно и командиром войск в западных губерниях, а в 1812- 1830 гг. управлял литовскими губерниями. Это те регионы, где церковная скульптура получила широкое бытование.

На территории Польши, Белоруссии, Западной, Средней и Северной Литвы иконографический извод - Христос в длинном облачении - был распространен с XVII века и составил более половины всех изображений Спаса Полунощного на этих территориях [Сурдокайте: 2009. С.50-66]

Нередко Христос в темнице изображался, закованным в кандалы. Один из памятников Радищевского музея иллюстрирует эту сцену ${ }^{14}$. (Илл. 4).

13. Христос в темнице. XIX в. Дерево, левкас, темпера; резьба, роспись. 113×53×43 Радищевский музей, СК 309, КП 4932 ССаратовский государственный художественный музей имени А.Н. Радищева

14. Христос в темнице. XVIII в. Дерево, левкас; резьба, роспись. $152 \times 41 \times 48$. Радищевский музей СК 313, КП 5007 ОСаратовский государственный художественный музей имени А.Н. Радищева 
Особенностью этой скульптуры стало соединение одних деталей, выполненных необычайно тщательно и других, оставленных абсолютно без резьбы. Так, например, тщательно вырезаны лик, левое ухо, грудная клетка, но даже не намечены детали с тыльной стороны. Терновый венец вырезан только до затылочной части головы, далее он переходит в ровную неоформленную резьбой ленту, что удивительно, так как венец имея особое сакральное значение, всегда изображался полностью. Волосы неглубокими подрезками разделаны только на первых локонах, лежащих на плечах и не даже разделены сзади на пряди. Спина и набедренная повязка сзади оставлены простым необработанным массивом и переходят в подставку странной формы, представляющей собой клин, идущий от крестца вниз. Очевидно, эта деталь имела определенное функциональное значение, например, как вставка, для соединения фигуры с сидением.

Скульптура вырезана практически из цельного деревянного массива, кроме небольшого дополнения. Надставлен и закреплен деревянными гвоздями локоть правой руки.

У Иисуса особенное выражение лица, связанное с необычной трактовкой глаз. Правый глаз приоткрыт, и из под нарисованных ресниц видена коричневая радужная оболочка. Левый глаз закрыт. Лик лессирован розовым пигментом, который прослеживается на губах и щеках. На голове Христа терновый венок, собранный из равновеликих ромбовидных сегментов. Условно и декоративно решены крупные складки набедренной повязки, спущенной так низко от пояса, что видны обнаженными чресла. На ногах Христа, вырезанные из дерева, кандалы.

В Саратовском областном музее краеведения храниться еще одна фигура Христа в кандалах ${ }^{15}$. Скульптура обладает рядом особенностей. Необычным является положение ног Христа. Спаситель изображен сидящим на высоком сидении, ноги не достают до пола, стопы в кандалах (сохранено только правое кольцо) висят. Кроме того, на теле Христа нет следов бичевания. Практически явлена только сцена осмеяния - Христос увенчан терном как ложной короной, но само истязание еще не произошло.

Голова Христа повернута к правому плечу. Пряди волос разбросаны по плечам и спине. Левое ухо открыто полностью, что отражает тему готовности слушания гласа Божьего На голове - зеленый терновый венец с вставными шипами. Тело Христа средне-темной карнации; темно-коричневые волосы, борода, усы, брови; карие глаза, розовые губы. Ладонь правой руки поднесена к щеке, левая рука прижата к торсу. Привлекает внимание пластическая трактовка крупных ребер. Красная набедренная повязка, моделированная множеством складок, спускается с левой стороны до середины голени и поднимается с другой стороны, обнажая правое колено. Эта деталь - обнаженное колено - встречается в саратовских памятниках несколько раз. Все произведения исполнены разными мастерами, поэ-

15. Христос в темнице. Саратовское Поволжье, XVIII в. Дерево, левкас, темпера, кованный ме-

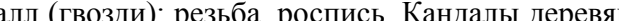
Саратовский областной музей, краеведения № СМК 74507, КП 55б Инв. № СКЛ 75 тому можно исключить авторский художественный прием. Возможно, имелся некоторый иконографический образец (гравюра, скульптура), который лег в основу такой трактовки набедренной повязки.

Среди наиболее выразительных образов Саратовской коллекции улыбающийся Христос с закрытым глазами ${ }^{16}$. Иисус представлен сидящим, в традиционной позе: ладонь правой руки у щеки, голова склонена вправо, волнистые волосы раскинуты по плечам, левая рука прижата к торсу на уровне живота. Скульптура отличается целым рядом уникальных деталей. Терновый венец не вырезан из единого с фигурой массива дерева, а сплетен из лозы и закреплен кованными гвоздями. Широкая ткань, скрывающая фигуру от пояса до середины голеней, уложенная крупными складками, откинута с левой стороны, оставляя левую ногу Христа обнаженной от колена.

Особенностью образа можно считать необычайно умиротворенное выражение лица с улыбкой на устах и с закрытыми глазами. Традиционно раскрытые глаза трактуются как символ торжества жизни над смертью, но закрытые - как символ смерти. В этой трактовке - ожидание распятия и предчувствие Божественного бессмертия в последние часы жизни Христа-человека - спокойного, умиротворенного, всепрощающего. Необычной также можно считать рану на груди слева, хотя известно, что удар копьем был нанесен распятому Иисусу справа. Подобные примеры встречаются крайне редко. Рану на груди слева можно так же увидеть у Христа в темнице (XVII в.) из собрания Переславль-Залесского музея заповедника.

С закрытыми глазами и улыбкой на устах изображен также Христос из села Кондоль Петровского уезда Саратовской губернии ${ }^{17}$. В образе улыбающегося Христа нет даже намека на страдание. Ладонь правой руки прижата к щеке. Левая рука прижата к торсу на уровне живота. Голова выдвинута впереди слегка склонена. Прямые темные волосы изысканно уложены. От лица волосы окинуты за плечи на спину. Складки набедренной повяз решены декоративным приемом. Памятник запечатлен на акварели Ф. Китавина в 1923 году ${ }^{18}$. Фигура представлена в облачении - белой накидке с кружевным краем. На шее Христа на красной ленте цветной медальон, возможно роспись по эмали.

Ряд скульптур их Саратовской коллекции, определенно принадлежат одному автору. Все они созданы по одной модели. Это говорит о наличии в регионе скульптурной мастерской, в которой создавалось резное убранство и статуарная пластика для храмового пространства. Три статуи из деревни Языковка Петровского уезда Саратовской губ, села Русская Норка, одного из сел Кузнецкого уезда, расположенного вблизи Петровска объединяют не только художественный почерк

Христос в темнице. XVIII в. Дерево; остатки левкаса, темперы; кованный металл (гвозди) 123×30×34. Радищевский музей, СК 315, КП 5009

Христос в темнице. ХІХ в. Дерево, левкас, темпера; резьба, роспись $109 \times 48 \times 40$. Радищевский музей, СК 320, КП 5014

в. Ф. Китавин. Истинный Христос. 1923. Бумага, акварель. 32,5×23,4см . Инв. № СМК 57722/21 
и пластическое тождество, но и геометрическое совпадение боковых профильных контуров. Торсы всех трех фигур необычайно уплощены, но головы, ноги и руки исполнены в полном объеме. Во всех случаях Спаситель изображен полуприсевшим, почти стоящим. Кончики пальцев правой руки слегка прикасаются к виску. Левая рука прижата к торсу на уровне живота. Голова ориентирована прямо и сильно выдвинута вперед. Шея склонена. Прямые темные волосы лежат крупными прядями на плечах и спине. У висков волосы слегка окинуты, открывая огромные уши, тонированные розовым в отличии от всей остальной карнации. Набедренник решен декоративно, складки не следуют анатомическим объемам. По бокам они сгруппированы в свободно спадающие вертикальные почти геометрические треугольные формы, в центре - уложены волнообразным объемом, пересекающим бедра Христа по диагонали.

Небольшие различия в статуях только в трактовке набедренной повязки скульптуры из села Русская Норка ${ }^{19}$ - центральная волнообразная складка уложенная по диагонали, выполнена зеркально по отношению к двум другим промерам.

На акварели Китавина у Христа из села Языковка ${ }^{20}$ темные волосы, борода, глаза и брови. Ясно прослеживается розовая карнация. Набедренная повязка светло-зеленого цвета. На лике, торсе, руках и ногах красные капли крови и длинные следы иссечённой кожи от ударов плетьми. Китавин зафиксировал, отсутствие (наполовину) стоп обеих ног. Утраченная в настоящее время рука на акварели изображена. Ладонь необычно далеко отведена от щеки.

Произведения Китавина отличаются редкой для живописных произведений фотографической точностью. Видно, что на момент создания акварели, памятник имел ряд утрат - трещины, сколы, частичные утраты поверхностного слоя зафиксированы с поразительной точностью. Но не смотря на это большая часть росписи в 1923 году еще была сохранена.

Оценивая большое разнообразие трактовок этого сюжета, необходимо принять во внимание, что на территории России статуи Христа в темнице создавались большей частью в провинциальный мастерских, где в качестве источника и образца у мастеров имелись только гравированные иллюстрации, которые трактовались порой весьма произвольно. Эти обстоятельства дали определенную свободу скульпторам и резчикам при создании пластических образов, отличающихся пластическим разнообразием и яркими эмоциональными характерами.

\section{БИБЛИОГРАФИЯ}

1. Аррас, Д. Деталь в живописи. СПб, 2010. С. 96-105

2. Theatrum biblicum hoc est Historiae sacrae Veteris et Novi Testamenti tabulis aeneis expressae. Opus... editum per Nicolaum Joannis Piscatorem. Amsterdam, 1643; 1650; 1674; Alcmar, 1646.

9. Христос в темнице. XVIII в. Дерево, левкас, темпера, кованный металл (гвоздь); резьба, роХристос в темнице. ХVII в. Дерево, левкас, темпера,
спись $128 \times 39 \times 34$. Радищевский музей. СК-317, КП 5011

20. Китавин Ф. «Истинный Христос». 1923. Бумага, акварель. 33,6×23 см Инв. Инв.СМК6813
3. Гаврилова Н. В. Каталогизация православной скульптуры из собраний музеев Саратовского Поволжья. // Научный сборник Древнерусская скульптура. Вып. V : Запад - Росского Поволжья. // Научный сборник Древнерусская

4. Габия Сурдокайте. // Иконография, распространение, назначение образа Спаса Полунощного в XVII-XX вв. в Великом княжестве Литовском и Литве. Научный сборник Древнерусская скульптура. Вып. VI Проблемы иконографии. М., 2009. С. $50-66$

5. Бараненков В.Ю. Письмо резчика XVII в. (из реставрационных находок). История и культура Ростовской земли. Материалы конференции 2005 г. Ростов, 2006. С. 139.

6. Библия Пискатора - настольная книга русских иконописцев/ Гос. Третьяковская галерея. М., 2019. С. 166-167

7. Бурганова Мария Александровна Русская сакральная пластика : диссертация ... доктора искусствоведения : 17.00.04. - Москва, 2002. - 312 с. : ил. + Прил. (с.313-477: ил. Бурганова Мария Александровна; [Место защиты: Федеральное государственное бюджетное образовательное учреждение высшего образования «Московская государственная художественно-промышленная академия им. С.Г. Строганова»].- Москва, 2002.- 321 8. H. Belting. The Image and Its Public in the Middle Ages. Form and Function of Early Paintings of the Passion. New York. 1990.

9. M-Museum Leuven. Catalog. Leuven, 2014

10. Бурганова М.А. Нидерландская гравюра и скульптура Троицкого собора ТроицеГледенского монастыря. Образ и прототип // Сборник «Архетип и универсалии в искусстве христианского мира от античности до современности: изобразительное и монументально-декоративное искусство, архитектура и предметно-пространственная среда» XXVI Международные Рождественские образовательные чтения: «Нравственные ценности и будущее человечества». 2018. С. 110-115.

11. Girelli, Francesca. 2018. "A masterpiece by the Master of the Courajod Christ in Normandy: a reconsideration of the crucifix of Saint-Marcel and other Norman Romanesque sculptures", Sculpture Journal, Liverpool University Press, vol.27, issue 2, pp. 157-176 https://doi. org/10.3828/sj.2018.27.2.2

12. Paoletti, John. (1992). Wooden Sculpture in Italy as Sacral Presence. Artibus et Historiae. DOI 13. $85.10 .2307 / 1483432$.

13. Girelli, F. A masterpiece by the Master of the Courajod Christ in Normandy: a reconsideration of the crucifix of Saint-Marcel and other Norman Romanesque sculptures // Sculpture Journal, 2018, vol. 27 (2), C.157-176. DOI 10.3828/sj.2018.27.2.2 (in English) 